\title{
Isolation and Identification of the Human Homolog of a New p53-Binding Protein, Mdmx
}

\author{
Avi Shvarts, ${ }^{1}$ Merlijn Bazuine, Patrick Dekker, Yolande F. M. Ramos, Wilma T. Steegenga, \\ Gerard Merckx,* Reinier C. A. van Ham, Willemien van der Houven van Oordt, \\ Alex J. van der Eb, and A. G. Jochemsen ${ }^{2}$
}

Laboratory of Molecular Carcinogenesis, Sylvius Laboratory, Leiden University, P.O. Box 9503, 2300 RA Leiden, The Netherlands; and *Department of Human Genetics, University Hospital Nijmegen, The Netherlands

Received November 4, 1996; accepted April 17, 1997

\begin{abstract}
We recently reported the identification of a mouse cDNA encoding a new p53-associating protein that we called Mdmx because of its structural similarity to Mdm2, a well-known p53-binding protein. Here we report the isolation of a cDNA encoding the human homolog of Mdmx. The ORF of the cDNA encodes a protein of 490 amino acids, $90 \%$ similar to mouse Mdmx. The homology between $\mathrm{Mdmx}$ and $\mathrm{Mdm} 2$ is most prominent in the p53-binding domain and the putative metal-binding domains. The Mdmx protein, which, based on SDS-PAGE, has a MW of $80 \mathrm{kDa}$, can bind $\mathrm{p53}$ in vitro. The human MDMX gene is transcribed in all tissues tested, with high levels in thymus. By fluorescence in situ hybridization analysis we mapped the mouse $\mathrm{mdmx}$ gene to chromosome 1 (region F - G) and the human MDMX gene to chromosome 1q32. 1997 Academic Press
\end{abstract}

\section{INTRODUCTION}

The loss of wild-type p53 in human malignancies results in aberrant cell-cycle progression, escape from apoptosis, and enhanced angiogenesis, which all contribute to tumor growth. These biological processes are most likely controlled by p53 through its transcriptionregulating function, which, in human tumors, is usually altered due to gene mutations (Hollstein et al., 1991, 1994), but can also take place via cytoplasmic retention (Moll et al., 1992, 1995) and by association with other proteins. Tumor antigens of several DNA tumor viruses have been shown to inactivate the function(s) of $\mathrm{p53}$, by a tight association (SV40-LT, adenovirus type 5 large E IB protein, HBV X-antigen; Lane and Crawford, 1979; Linzer and Levine, 1979; Sarnow et al., 1982; Zantema et al., 1985; Feitel son et al., 1993),

\footnotetext{
${ }^{1}$ Present address: Division of Molecular Carcinogenesis, Netherlands Cancer Institute, 1066 CX Amsterdam, The Netherlands.

2 To whom correspondence should be addressed. Telephone: (31) 71 5276136. Fax: (31) 715276284. E-mail: A.G.J ochemsen @biochemistry. MedFac.LeidenUniv.NL.
}

by enhanced degradation of the p53 protein (HPV-E6; Scheffner et al., 1990; Werness et al., 1990), or by as yet unknown ways, possibly involving altered oligomerization of p53 (adenovirus type 12 large E 1B, adenovirus type 5 E 1A; Steegenga et al., 1995, 1996). I mportantly, HPV and HBV have been implicated in human cervical carcinoma and liver carcinoma (Srivastava et al., 1992; Ueda et al., 1995), respectively. In addition, some cellular proteins have been found to bind to p53 and influence its properties as a transcription factor. First, the Wilms' tumor protein WT1, a transcription factor itself, is able to modulate p53-regulated transcription (Maheswaran et al., 1993). Recently, theE 2F 1 and DP1 proteins were also shown to interact directly with p53 and inhibit its transcription-stimulation function (O'Connor et al., 1995; Martin et al., 1995). Last, p53 was found to complex with the Mdm2 protein (Barak and Oren, 1992; Momand et al., 1992). The association of $\mathrm{Mdm} 2$ with p53 completely abrogates all transcription-regulating properties of p53 (Momand et al., 1992; Chen et al., 1995). Mdm2 most likely functions by concealing the transactivation domain of p53 (Oliner et al., 1993). Most interestingly, overexpression of $\mathrm{Mdm} 2$ has been found in a variety of tumors, in general correlating with the absence of mutations in the p53 gene (Oliner et al., 1992; Reifenberger et al., 1993; Habuchi et al., 1994; Lianes et al., 1994; Corvi et al., 1995). Overexpression of $\mathrm{Mdm} 2$ is apparently sufficient for inhibition of the p53 tumor-suppression function. Thus, inactivation of p53 in human tumors can be achieved by mutation, cytoplasmic retention, or overexpression of $\mathrm{Mdm} 2$, or by several viral proteins.

We recently reported the identification of a new p53associating protein. The translation product of this gene, named $m d m x$, shows significant homology with the $\mathrm{Mdm} 2$ protein, especially in the p53-binding domain and in the putative functional domains, located in the C-terminal part of the protein. We reported that the murine $\mathrm{Mdmx}$ protein binds to $\mathrm{p53}$ in vivo and, like Mdm2, inhibits the activation of transcription by $\mathrm{p53}$ (Shvarts et al., 1996). Unlike mdm2, which is a p53- 
responsive gene, mdmx transcription appears not to be regulated in a p53-dependent manner, at least not after UV irradiation. This might suggest that $m d m x$ is not a modifier of p53 after UV irradiation. We now report the isolation of a human cDNA of 2216 bp that encodes the human Mdmx protein of 490 aa. The mouse and human Mdmx proteins have $90 \%$ identity at the protein level. We show that the human Mdmx protein binds to p53 in vitro. By FISH analysis we mapped the mouse mdmx gene to chromosome 1 region $F-G$ and its human homol og to chromosome 1q32. We report the identification of a new member of the mdm family that might be involved in human carcinogenesis.

\section{MATERIALS AND METHODS}

Northern analysis. A human multitissue Northern blot (Clontech) was hybridized with ${ }^{32} \mathrm{P}$-label ed probes according to the manufacturer's manual.

Isolation and sequencing of human MDMX cDNA. A CDNA library from the col onic epithelial cell line T84 in a UNI-Zap-XR vector (Stratagene) was screened with mouse mdmx cDNA probe according to the protocol supplied by the manufacturer. pBSK plasmids containing the human MDMX CDNA were obtained with R408 helper phage (Stratagene).

Double-stranded DNA was sequenced by a T7 polymerase sequencing kit and AutoRead Sequencing kit (Pharmacia). The sequence reactions were subsequently analyzed manually on polyacrylamide gel and by the ALF (automatic laser fluorescence) DNA sequencing machine (Pharmacia). All the sequence primers were obtained from I sogene Bio-Science B.V.

I solation of genomic mdmx DNA clones. To obtain genomic mouse mdmx sequences, we screened a genomic mouse library derived from 129/OLA mice in EMBL3A phage using the standard procedure (Sambrook et al., 1989). Subclones were generated by digestion with Sall and by cloning the fragments into Sall-digested pl C20R vector. To obtain human MDMX genomic sequences, library N0. 700 (P1 human), ligated into pAd10SacBII (Francis et al., 1994), was screened with a fragment of approximately $560 \mathrm{bp}$ obtained by RTPCR on mRNA isolated from the human tumor cell line G401 (Weismann et al., 1987) with a primer set corresponding to nt 460-478/ 1003-1022. The presence of MDMX-specific sequences in the genomic clones was established by Southern blot analysis with the use of specific cDNA probes (data not shown).

In vitro associations between $\mathrm{Mdmx}$ and $\mathrm{p53}$. To obtain in vitro translated $M d m x$ proteins, the full-length coding regions of mouse and human Mdmx were cloned into pcDNA3 vector (I nvitrogen). Human p53 protein was translated in vitro from the modified pET15b/ p53 vector (Shvarts et al., 1996) and the human cJ un protein from a pBAT vector (Annweiler et al., 1991) containing the human cJ un coding region (pBAT-c) un, a gift from Dr. P. Angel, Karlsruhe, Germany).

In vitro transcription/translation was performed with the use of the coupled transcription/translation system obtained from Promega (Madison, $\mathrm{WI}$ ) in the presence of $\left[{ }^{35} \mathrm{~S}\right]$ methionine. In vitro translated $\mathrm{Mdmx}$ proteins were incubated in the presence or absence of bacterially produced p53 proteins (Shvarts et al., 1996) for 30 min on ice. Subsequent immunoprecipitations were performed as described previously (Steegenga et al., 1995) with a mixture of the monoclonal antibodies PAb122/PAb421 directed against p53, the polyclonal rabbit antiserum pAb100 directed against a peptide of mouse $\mathrm{Mdmx}$, or the polyclonal rabbit antiserum pAb55 raised against full-length human Mdmx.

To obtain GST - human Mdmx fusion protein, the total coding region of human Mdmx was cloned into vector pRP259, a modified pGEX expression vector (Smith and J ohnson, 1988). Approximately $1 \mu \mathrm{g}$ of GST-Mdmx, bound to beads, was tumbled for $4 \mathrm{~h}$ at $4^{\circ} \mathrm{C}$ with labeled in vitro translated p53. Subsequently the beads were washed three times with binding buffer. Immunoprecipitated and GST - Mdmx-bound proteins were separated on a 9\% SDS-polyacrylamide gel, prepared for fluorography with $22.5 \%$ PPO (2,5- diphenyloxazole) in dimethylsulfoxide, dried, and exposed to Kodak XAR-5 film at $-80^{\circ} \mathrm{C}$.

Fluorescence in situ hybridization (FISH). FISH was performed on mouse cells regenerated from a muscle biopt and on human lymphocytes. Metaphase spreads were prepared via the standard procedures. A total of 400 and $150 \mathrm{ng}$ labeled mdmx probe for mouse and human chromosomes, respectively, and 50x mouse Cot I and 50x human Cot I DNA (Gibco, Life Technology) was dissolved in $12 \mu \mathrm{l}$ of a hybridization solution ( $50 \% \mathrm{v} / \mathrm{v}$ deionized formamide, $10 \%$ dextran sulfate, $2 x$ SSC, $1 \%$ v/v Tween $20, \mathrm{pH} 7.0$ ). Prior to hybridization, the probe was denatured at $80^{\circ} \mathrm{C}$ for $10 \mathrm{~min}$, chilled on ice, and incubated at $37^{\circ} \mathrm{C}$ for $30 \mathrm{~min}$ allowing preannealing. After denaturation of the slides, probe incubations were carried out under an 20 $\times 20 \mathrm{~mm}$ coverslip in a moist chamber for $45 \mathrm{~h}$. I mmunocytochemical detection of the hybridizing probe was achieved with FITC-conjugated sheep-anti-digoxigenin (Boehringer).

For evaluation of the chromosomal spreads a Zeiss epifluorescence microscope equipped with the appropriate filter for visualization of DAPI and FITC fluorescence was used. Digital images were acquired with a high-performance cooled CCD camera (Photometrics, Tucson) and further processed on a computer with the help of the BDS-Image FISH software package (Biological Detection Systems Inc, Rockville, MD).

\section{RESULTS}

Molecular Cloning of mdmx cDNA

To identify the human MDMX CDNA we screened a cDNA library from the col onic tumorigenic cell line

\section{Construction of human MDMX cDNA}
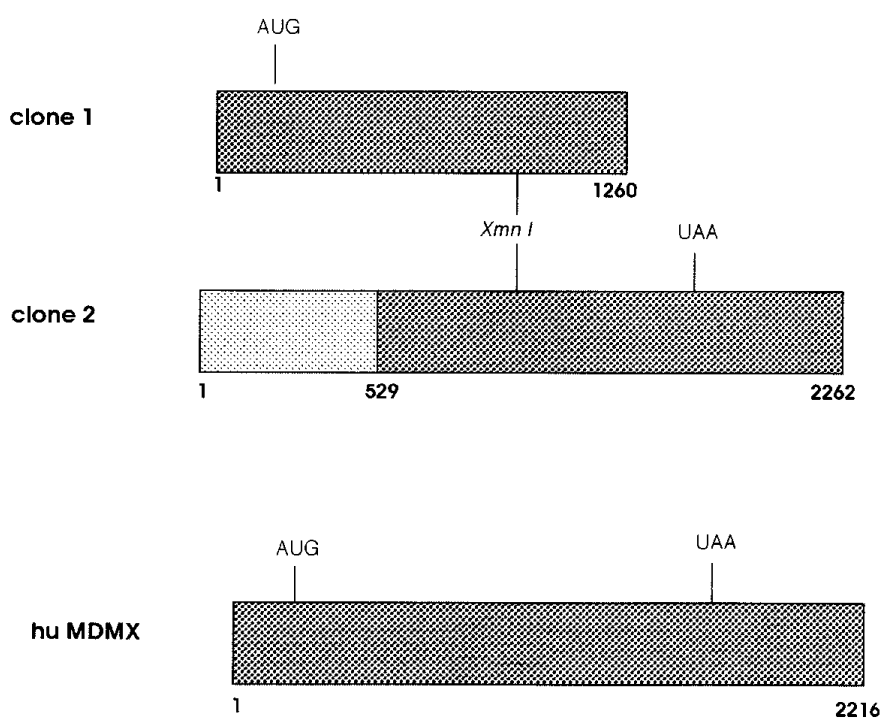

Human mdmx; homologous to human mam2

Human mamx intron sequence?

FIG. 1. Schematic representation of human MDMX CDNA clones obtained from a LambdaZap cDNA library from colon carcinoma cell line T84. The Xmnl site in the middle of the cDNA has been used to obtain the human MDMX cDNA containing the complete open reading frame. 
61 CGGCACGAGCTAGGATCTGTGACTGCCACCCCTCCCCCCACCCGGGCTCGGCGGGGGAGC GACTCATGGACTGCCGTAAGTTTTACCAACAGACTGCAGTTTCTCACTACCAAAATGA

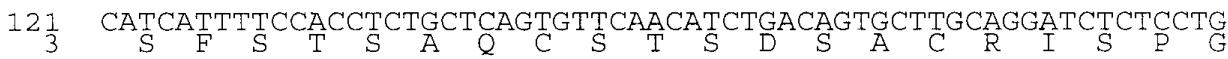

181 GACAAATCAATCAGGTACGACCAAAACTGCCGCTTTTGAAGATTTTGCATGCAGCAGGTG

241 CGCAAGGTGAAATGTTCACTGTTAAAGAGGTCATGCACTATTTAGGTCAGTACATAATGG

TGAAGCAACTTTATGATCAGCAGGAGCAGCATATGGTATATTGTGGTGGAGATCTTTTGG

$\underset{\mathrm{E}}{\text { GAGACTACTGGGACGTCAGAGCTTCTCCGTAAAGAACCCAAGCCCTCTCTATGATATGC }} \underset{\mathrm{L}}{\mathrm{L}}$

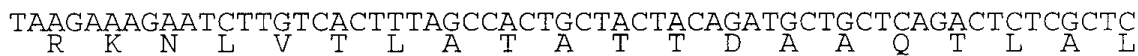
TCGCACAGGATCACAGTATGGATATTCCAAGTCAAGACCAACTGAAGCAAAGTGCAGAGG AAAGTTCCACTTCCAGAAAAAGAACTACAGAAGACGATATCCCCACACTGCCTACCTCAG

143

601
163

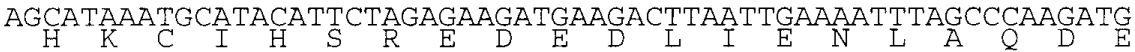

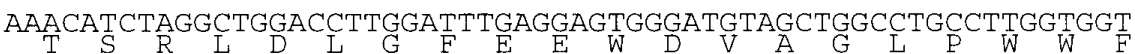

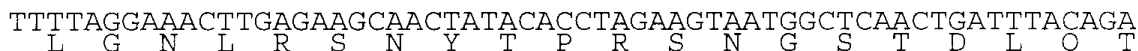

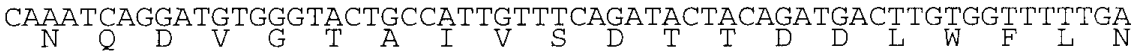

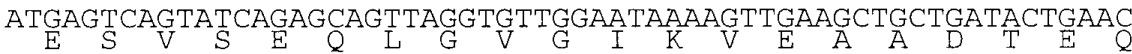
AAACAAGTGAAGAAGTAGGGAAAGTAAGTGACAAAAAGGTGATTGAAGTGGGAAAAAATG ATGACCTGGAGGACTCTAAGTCCTTAAGTGATGATACCGATGTAGAGGTTACCTCTGAGG

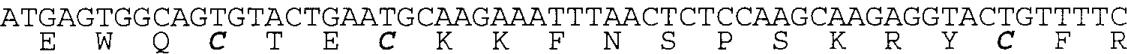
GTTGTTGGGCCTTGAGGAAGGATTGGTATTCAGATTGTTCAAAGTTAACCCATTCTCTCT CCACGTCTGATATCACTGCCATACCTGAAAAGGAAAATGAAGGAAATGATGTCCCTGATT

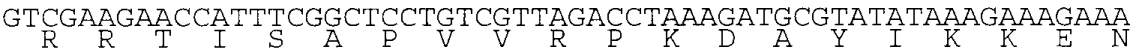
ACTCCAAACTTTTTGATCCCTGCAACTCAGTGGAATTCTTGGATTTGGCTCACAGTTCTG AAAGCCAAGAGACCATCTCAAGCATGGGAGAACAGTTAGATAACCTTTCTGAACAGAGAA CAGATACAGAAAACATGGAGGATTGCCAGAATCTCTTGAAGCCATGTAGCTTATGTGAGA $\begin{array}{llllllllllllllllllll}D & T & E & N & M & E & D & C & Q & N & L & L & K & P & C & S & L & C & E & \underline{K}\end{array}$

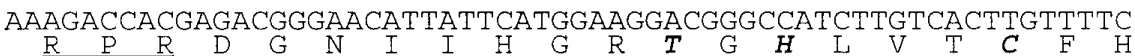
1501 ACTGTGCCAGAAGACTAAAGAAGGCTGGGGCTTCATGCCCTATTTGCAAGAAAGAGATTC

FIG. 2. Nucleotide and derived amino acid sequence of human MDMX. (A) Nucleotide sequence of MDMX CDNA and predicted protein sequence The putative AUG codon is underlined and boldface; putative alternative translation start sites are shown in boldface. Conserved cysteines in the putative zinc-finger and in the RING finger domains together with the core amino acids are given in boldface italics, and a putative nuclear localization signal is underlined. (B) Sequence alignment of Mdm-like proteins.

T84 (Stratagene) with a mouse mdmx cDNA probe (see Materials and Methods). Two independent phage clones, which remained positive after three rounds of purification, were isolated and purified to homogeneity. Sequence analysis showed inserts of 1260 and 2260 bp (clone 1 and clone 2, respectively, in Fig. 1).
The shortest construct shows a strong homology with the $5^{\prime}$ part of the previously identified mouse $\mathrm{mdmx}$ cDNA (Shvarts et al., 1996), including the putative translation start site. Sequencing of the longest construct revealed that in the $3^{\prime}$ part of the insert a stretch of 1143 bp shows a strong similarity with the 
Human MDMX Mouse MDMX Human MDM2 Mouse MDM2

Human MDMX Mouse MDMX Human MDM2 Mouse MDM2

Human MDMX Mouse MDMX Human MDM2 Mouse MDM2

Human MDMX Mouse MDMX Human MDM2 Mouse MDM2

Human MDMX Mouse MDMX

Human MDM2

Mouse MDM2

Human MDMX Mouse MDMX Human MDM2 Mouse MDM2

Human MDMX Mouse MDMX Human MDM2 Mouse MDM2
M. .TSFSTSA QCSTSDSACR ISPGQINQVR PKLPLLKILH AAGAQGEMFT $\bar{M}$..TSHSTSA QCSASDSACR ISSEQISQVR PKLQLLKILH AAGAQGEVFT MCNTNMSVPT DGAVTTSQIP AS.EQETLVR PKPLLLKLLK SVGAQKDTYT $8 \overline{1}$

DLLGELLGRQ SFSVKNPSPL YDMLRKNLVT LATATTDAAQ TLALAQDHSM DLLGDLLGCQ SESVKDPSPL YDMLRKNLVT SASNNTDAAQ TLALAQDHTM DLLGDLFGVP DLLGDVFGVP 161

TLPTSEHKCI HSREDEDLIE NLAODETSR. TLPTSRHKCR DSRADEDLIE HLSQDETSR. RPSTSSRRRA TSETEFNSDF I SGERORKRH RLSTSSRRRS ISETEENTDE LPGERHRKRR 241

SDTTDDLWFL NESVSEOLGV GIKVEAADTE SDTTDDLWFL NETVSEQLGV GIKVEAANSE EHSGD..WLD QDSVSDQFSV EFEVESLDSE EHSGD. . CLD QDSVSDQFSV EFEVESLDSE 321

TECKKENSPS KRYCERCWAL RKDWYSDCSK TECKKFNSPS KRYCFRCWAL RKDWYSDCSK TSCNEMNPPL PSHCNRCWAL RENWLPEDKG TSCNEMNPPL PSHCKRCWTL RENWLPDDKG 401

LFDPCNSVEF LDLAHSSESQ ETISSMGEQL .FDPCNSVGE LDLAHSSESQ EIISSAREQT ITQASQSQES EDYSQPSTSS SIIYSSQEDV AEQTPLSQES DDYSQPSTSS SIVYSSQESV
481
510

FHCARRLKKA GASCPICKKE IQLVIKVFIA FHCARRLKKS GASCPVCKKE IQLVIKVFIA FTCAKKLKKR NKPCPVCRQP IQMIVLTYEP FTCAKKLKKR NKPCPVCRQP IQMIVLSYFN

LTHSLSTSDI TAIPE. KENE LTHSLSTSNI TAIPEKKDNE KDKGEISEKA KLENSTQAEE KDKVEISEKA KLENSAQAEE DNLSEQRTD. DIFSEOKAE. TESMEDF. KEFEREETQD KEESVESSLP KEL.KEETOH KDESVESSFS 0

VKEVMHYLGQ YIMVKQLYDQ QEQHMVYCGG MKEVMHYLGQ YIMVKQLYDQ QEQHMVYCGG MKEVLFYLGQ YIMTKRLYDE KQQHIVYCSN MKEIIFYIGQ YIMTKRLYDE KQQHIVYCSN

160

DIPSO..DOL KOSAEESSTS RKRTTEDDIP DFPSQ..DRL KHGATEYSNP RKRTEEEDTH EGGSDQKDLV QELQEE......KPSSSHLVS EGGSDLKDPL QAPPEE.... . KPSSSDLIS 240

...LDLGEE EWDVAGLPWW FLGNLRSNYT PRSNGSTDLO TNODVGTAIV .LDLDFE EWDVAGLPWW FLGNLRNNCI PKSNGSTDLQ TNQDIGTAIV KSDSISLSED ESLALCVIRE ICCE.....R SSSSESTGTP SNPDLDAGVS R....SLSED PSLGLCELRE MCSGGTSSSS SSSSESTETP SHQDLDDGVS 320

QTS.....EE VGKVSDKKVI EVGKNDDLED SKSLSDDTDV EVTSEDEWQC QTS.......E VGKTSNKKTV EVGKDDDLED SRSISDDTDV ELTSEDEWQC DYSLSEEGQE LSDEDDEVYQ VTVYQAGESD TDSFEEDPEI SLA..DYWKC DYSLSDEGHE LSDEDDEVYR VTVYQTGESD TDSEEGDPEI SLA..DYWKC

GNDVPDCRRT ISAPVVRPKD AYIKKE.NSK GIDVPDCRRT ISAPVVRPKD GYLKEE.KPR GFDVPDCKKT I...VVNDSRE SCVEEN.DDK GLDVPDGKKL T...ENDAKE PCAEEDSEEK 480

QNLLKPCSLC EKRPRDGNII HGRTGHLVTC QNVLKPCSLC EKRPRDGNII HGKTSHLTTC LNAIEPCVIC QGRPKNGCIV HGKTGHLMAC LNAIEPCVIC QGRPKNGCIV HGKTGHLMSC

\section{FIG. 2-Continued}

$3^{\prime}$ part of the mouse mdmx cDNA, including the translation stop codon. Clone 1 and clone 2 showed a 700-bp identical sequence (Fig. 1). Comparing these available sequences with the mouse mdmx CDNA and the human MDM 2 CDNA sequence suggested that these $700 \mathrm{bp}$ are a real overlap, al lowing us to generate a human MDMX CDNA with the use of an unique $\mathrm{Xmnl}$ recognition site present in the 700-bp overlap. RT-PCR analysis on mRNAs from normal human cells and a human tumor cell line with primers from outside the overlapping region yiel ded a fragment of a length expected from the combined CDNA (data not shown). The human MDMX CDNA is at the $3^{\prime}$ end, approximately $500 \mathrm{bp}$ longer than the thus far identified mouse mdmx cDNA because of a longer 3'-untranslated region. This $3^{\prime}$ UTR is similar to that of the human MDM2 CDNA in that it contains an Alu repeat as has been described for the MDM2 CDNA. This human MDMX CDNA contains an open reading frame of 490 amino acids with strong homology to the mouse $\mathrm{Mdmx}$ protein sequence ( $\mathrm{Fig} .2 \mathrm{~A}$ ).

At the moment we do not know for sure the exact nature of the $5^{\prime}$ part of the CDNA insert of clone 2. However, we propose this part to be intron sequences, because comparison with the genomic organization of the mouse $\mathrm{mdm} 2$ gene indicates that the junction be tween the unknown 5' sequences and the M dmx-homology region is exactly at a splice acceptor site ( ones et al., 1996; Montes de Oca Luna, 1996). Another explanation for the presence of these sequences is not excluded.
Sequence alignment of human MDMX with human MDM2 revealed, analogous to mouse $\mathrm{mdmx}$, a significant homology at both the DNA and the protein levels. Figure $2 A$ shows the CDNA sequence of human MDMX and the putative open reading frame, encoding a protein of $490 \mathrm{aa}$. The sequence alignment of the $\mathrm{Mdm}$ like proteins is shown in Fig. 2B. All proteins share the p53-binding site, which is located in their $\mathrm{N}$-terminus (Chen et al., 1995; Brown et al., 1993; Haines et al., 1994; Shvarts et al., 1996). The Mdm2 mRNAs contain additional AUG codons at positions +50 and +62 , which have been shown to be real alternative translation start sites in both in vivo and in vitro translation assays (Barak et al., 1994; Zauberman et al., 1995). These AUGs are also present in the $\mathrm{mdm} x$ sequence at approximately the same positions $(+46,+53$, and +61 ). We have no direct evidence that they function as alternative starts in the MDMX mRNA, although in vitro translation yields protein products of the expected size, but also of a smaller size (see below). It suggests that the MDMX mRNA might give rise to different protein products, as has been described for $\mathrm{Mdm} 2$. At the Cterminus the putative metal-binding domains, residues 306 to 323 and residues 439 to 479 in the human Mdmx protein, are highly conserved between the different $\mathrm{Mdm}$ family members. The latter domain has recently been reported to be structurally related to a zinc-binding domain called the RING finger (Boddy et al., 1994). All $\mathrm{Mdm}$ proteins contain a putative nuclear localization signal (Figs. 2A and 2B). However, the nuclear 


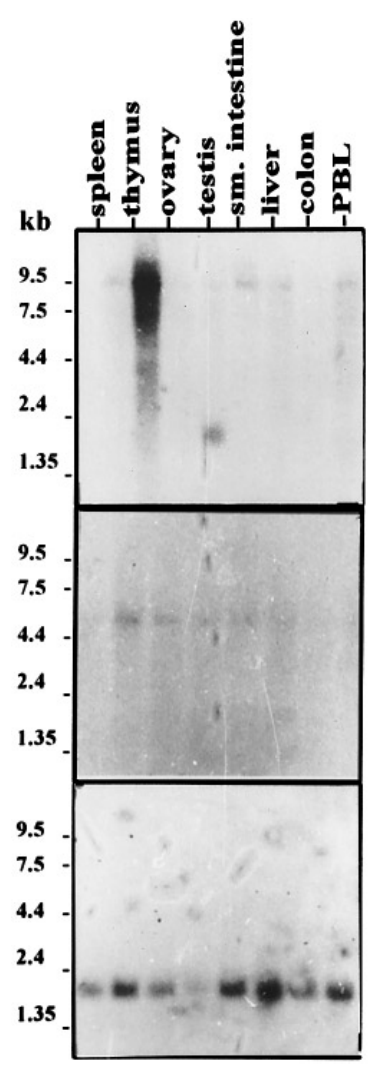

FIG. 3. Expression of MDMX mRNA in human tissues. (A) Northern blot containing poly $(A)^{+}$-selected mRNA from human tissues was probed with human MDMX CDNA. (B) The same bl ot was probed with human MDM2 CDNA. (C) Human $\beta$-actin CDNA was used as control for the amount of mRNA loaded. Positions of molecular-weight markers (kb) are indicated.

localization signal of the $\mathrm{Mdm} 2$ protein is found at positions 178- 183 (RKRHK), in the middle part of the protein, whereas in the human $M d m x$ protein it is found at positions 442-445 (KRPR) in the C-terminal part.

\section{Expression of MDMX mRNAs in Human Tissues}

To determine the expression pattern of human MDMX mRNA we performed Northern blot analysis on a human multi tissue blot. Figure $3 \mathrm{~A}$ shows that a $10-k b$ human MDMX transcript is synthesized in all tissues, with the highest amount in the thymus and a very low expression in colon. An additional shorter transcript of approximately $2.2 \mathrm{~kb}$ is detectable in testis. We do not know the exact nature of the different mRNAs, but the mRNA expression pattern of the mouse and the human is rather conserved and will be discussed in more detail later. F urthermore, expression of human MDMX mRNA was found in all tissues and cell lines tested by RT-PCR (data not shown). We compared the expression of human MDMX with that of MDM2 by reprobing the same blot with an MDM2 probe (Fig. 3B). The human MDM2 gene was previously shown to be expressed in a $5.5-\mathrm{kb}$ transcript, first identified by Oliner et al. (1992) predominantly in skeletal muscle and liver, with somewhat lower levels in pancreas and lung (Ladanyi et al., 1993). A 5.5-kb MDM2 transcript was detected, but we find the MDM2 gene to be almost equally expressed in all tissues on this blot with only a somewhat higher expression in the thymus, but certainly not as prominent as the MDMX transcript.

\section{In Vitro Interaction between Mdmx and p53}

We have shown previously that mouse Mdmx can bind p53 in vivo (Shvarts et al., 1996). To investigate the in vitro interaction between human and mouse Mdmx and human p53, we performed two types of experiments. First, we mixed in vitro translated, ${ }^{35} \mathrm{~S}-\mathrm{la}-$ beled Mdmx with bacterially produced and purified p53 protein (see Materials and Methods). After this incubation immunoprecipitations with anti-p53 and antiMdmx antibodies were performed.

The results presented in Figs. $4 \mathrm{~A}$ and $4 \mathrm{~B}$ demonstrate that in the presence of $\mathrm{p} 53$ protein significant amounts of the in vitro translated human and mouse $\mathrm{Mdmx}$ proteins are coimmunoprecipitated with a mixture of the anti-p53 antibodies PAb 122/PAb 421. F urthermore, it seems that only the upper band of mouse Mdmx, which is probably generated from the first inframe AUG, interacts with p53, suggesting that the protein lacking the $\mathrm{N}$-terminal part does not bind $\mathrm{p} 53$. Although difficult to see in Fig. 4, the same seems to be true for the human Mdmx. To verify the in vitro binding association between human Mdmx and p53, a GST - Mdmx fusion protein was coupled to glutathione beads and incubated with ${ }^{35} \mathrm{~S}$-labeled, in vitro translated human p53 or c un as a control. As can be seen in Fig. 4C, the GST - Mdmx protein specifically interacts with human p53 and not with cl un, while GST alone binds neither protein.

We conclude from these results that both human and mouse $\mathrm{Mdmx}$ proteins associate with p53 protein in vitro and that the binding domain is probably located in the extreme $\mathrm{N}$-terminal part of the $\mathrm{Mdmx}$ proteins.

\section{Chromosomal Mapping of the mdmx Genes}

Amplification of the human MDM2 gene has been observed in a variety of tumors (Oliner et al., 1992; Reifenberger et al., 1993; $\mathrm{H}$ abuchi et al ., 1994; Lianes et al., 1994; Corvi et al., 1995). Since the MDMX gene might be present in amplicons described in human tumors, we set out to local ize the gene. To begin with, the mouse mdmx gene was mapped with FISH to chromosome 1, region F-G (Lyon and Searle, 1989; Figs. $5 A$ and $5 B$ ). This region is in synteny with a region on the long arm of the human chromosome 1. This possible location of the human MDMX gene was verified by FISH analysis with the PI clone containing human MDMX sequences. The human MDMX gene was mapped to human chromosome 1q32 (Figs. 5C and 5D). This region was recently reported to be amplified in a subset of liposarcomas 
A
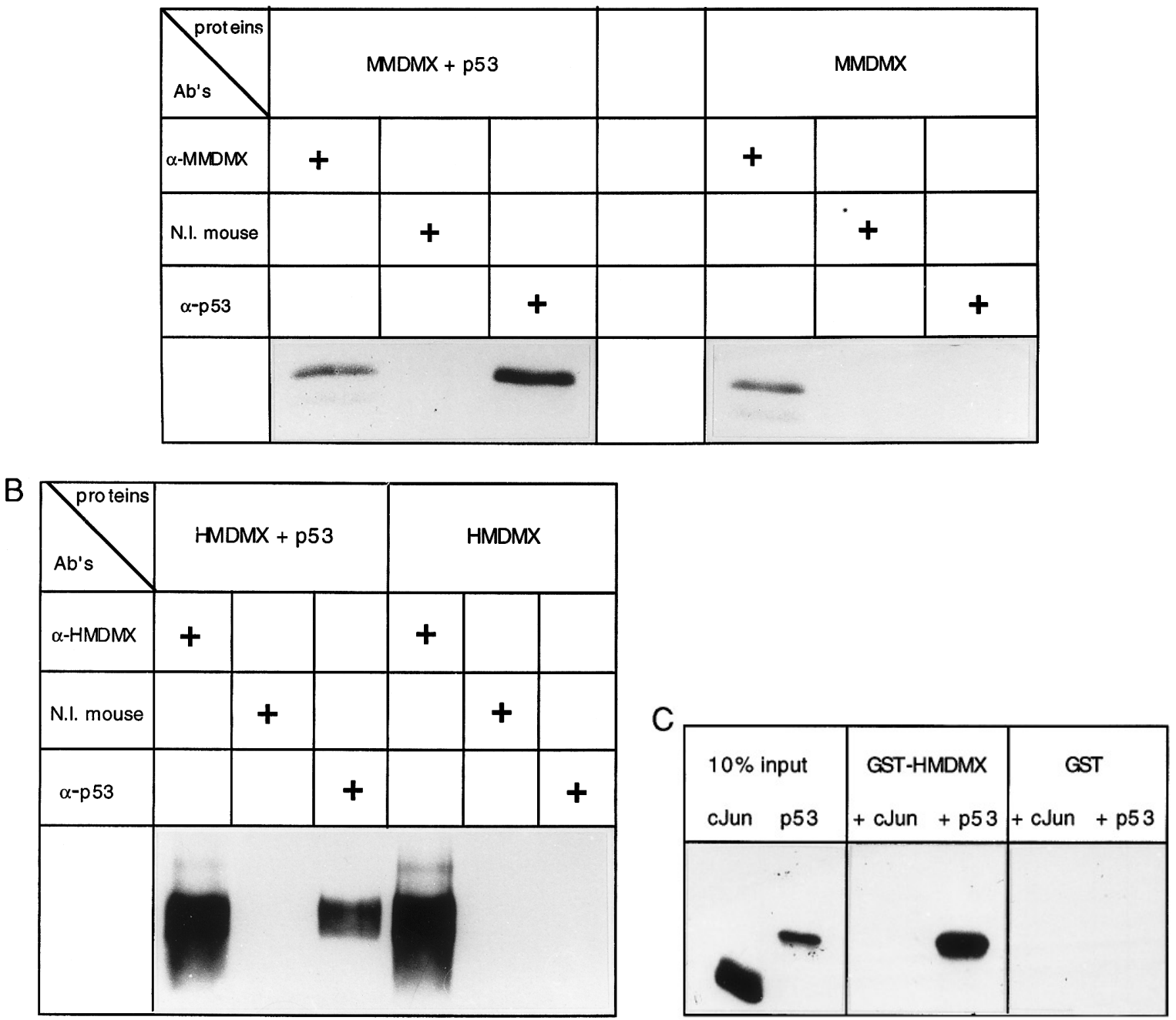

FIG. 4. In vitro association between $M d m x$ and $p 53$. (A, B) I mmunoprecipitations on a mixture of in vitro translated, ${ }^{35} \mathrm{~S}$-Iabeled $M d m x$ proteins and bacterially produced p53 with a mouse M dmx-specific polyclonal antibody pAb100 ( $\alpha$ MMDMX), a polyclonal antibody recognizing human Mdmx pAb55 ( $\alpha \mathrm{HMDMX}$ ), or a mixture of PAb 122/421 ( $\alpha$ p53); nonimmune mouse antibody (N.I. mouse) was used in control immunoprecipitations as indicated. (C) GST - HMDMX fusion protein or only GST bound to glutathione beads was mixed with either in vitro translated ${ }^{35} \mathrm{~S}$-labeled $\mathrm{p} 53$ protein or $\mathrm{c}$ un protein. After this incubation the beads were washed and bound proteins were separated on SDS-PAGE.

(Szymanska et al., 1996; F orus et al., 1995). The possible amplification of the MDMX gene in these tumors is currently under investigation.

\section{DISCUSSION}

We report here the isolation and identification of the human counterpart of the mouse mdmx gene. The human MDMX gene encodes a protein of 490 aa that is $90 \%$ homol ogous to mouse $\mathrm{Mdmx}$ (Shvarts et al., 1996). The amino acid sequence predicts a protein with a theoretical molecular weight of $54 \mathrm{kDa}$. However, on SDSPAGE human $\mathrm{Mdmx}$ was found to migrate as a protein with a molecular weight of approximately $80 \mathrm{kDa}$. This behavior corresponds to the observation that the $\mathrm{Mdm} 2$ protein also runs at a much higher molecular weight on SDS-PAGE than expected from its amino acid se- quence. We expect the $\mathrm{Mdmx}$ amino acid sequence to be as presented here, since upstream from the putative AUG, in-frame stop codons are found. The apparent molecular weight of human $\mathrm{Mdmx}$ is somewhat larger than that earlier found for mouse $M d m x$. This might be caused by different posttranslational modifications, e.g., phosphorylation, which is known to occur on the Mdm2 proteins.

A sequence comparison between human MDMX and human MDM2 reveals conservation that is strongest in the p53-binding domain located in the $\mathrm{N}$-terminal part of both proteins. Furthermore, putative functional domains in the C-terminal part of the proteins are highly conserved. These domains consist of a zinc finger and a zinc-binding domain called the RING finger. The latter is thought to be involved in protein-protein interaction (Boddy et al., 1994). 

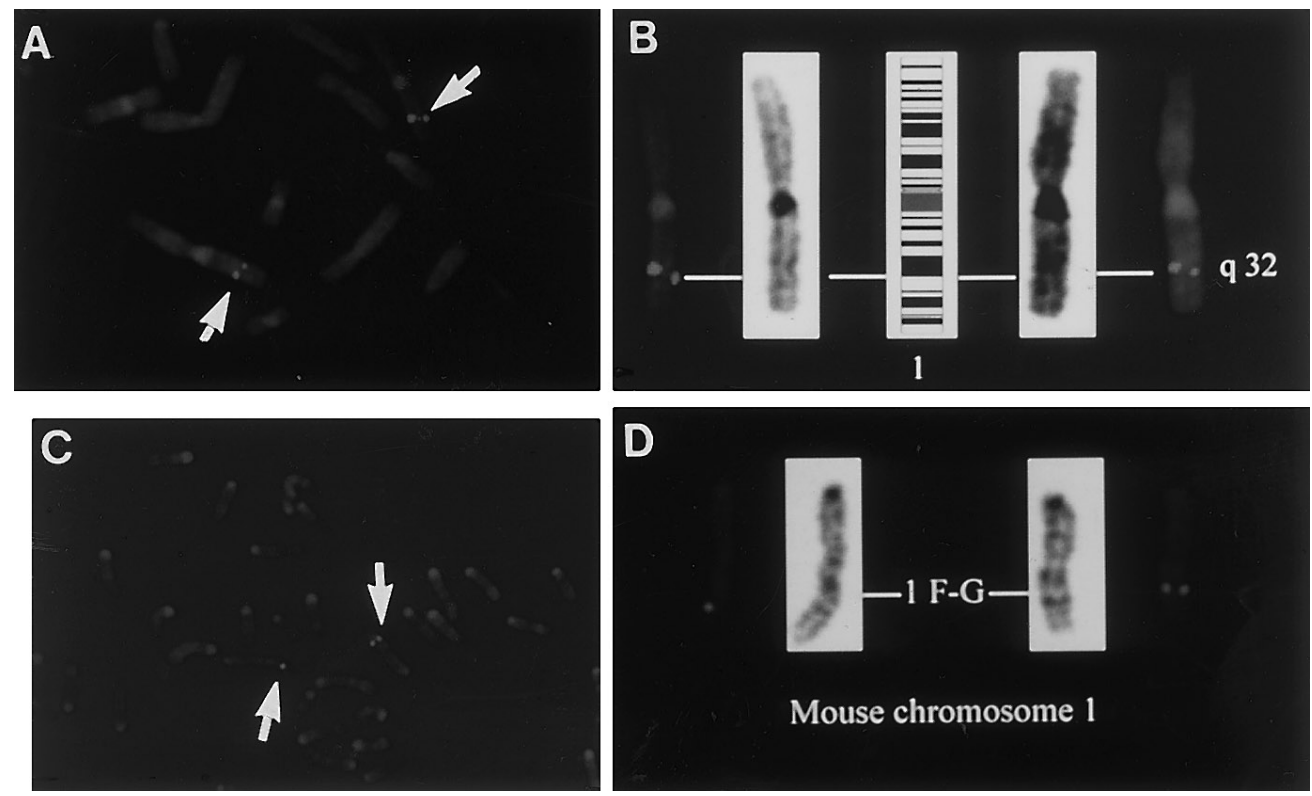

FIG. 5. Chromosomal localization of the $m d m x$ genes by fluorescence in situ hybridization. (A, C) Mapping of the mdmx gene on mouse and human metaphase chromosomes, respectively. Probe DNA, light spots; chromosomes are counterstained with DAPI. (B, D) Giemsalike banding to identify the chromosome and localize the probe on mouse chromosome $1 \mathrm{~F}-\mathrm{G}$ and on human chromosome 1 q32. At least 20 informative chromosome spreads were used to determine the localization of the mdmx genes.

By Northern blot analysis we detect a 10-kb transcript of human MDMX in most tissues, with a relatively high expression in thymus. Also mouse thymus was found to express relatively high levels of the murine mdmx mRNAs (data not shown). The murine mdmx gene is expressed prominently into two long mRNAs of approx. 10 and $7.5 \mathrm{~kb}$ in all tested tissues and a mRNA of $2.2 \mathrm{~kb}$, which is highly expressed in testis and to a very low level in other tissues (Shvarts et al., 1996). An MDMX mRNA of approx. $2.2 \mathrm{~kb}$ is also found in human testis. This mRNA is not detected in the other tissues, but if the expression of this mRNA in the other tissues is as low relative to the longer mRNA as in mouse tissues, it might be a detection problem. Thus, the mRNA expression patterns of the human and mouse mdmx genes are rather similar, with the possible exception of the shorter mRNAs in tissues other than testis. It is not firmly established whether the mRNAs detected all contain the coding region here presented. However, we hypothesize that the longer hybridizing RNA band represents not (fully) processed mRNA because of the following reasons. First, the cDNA clone 2 we isolated most likely contains intron sequences, while the library was made from oligo(dT)- primed mRNAs. Second, an entry in the NCBI EST database of 275 bp (L44283), derived from human thymus RNA, is identical over a stretch of $113 \mathrm{bp}$ with the human MDMX cDNA sequence shown here (Fig. 6). From studies on the genomic organization of the mouse gene we know this to be exon 2. Both $5^{\prime}$ and $3^{\prime}$ of these exon sequences the sequence of the EST diverges from the cDNA sequence (Fig. 6), but now shows similarity with intron sequences of the mouse mdmx gene (not shown). These results al ready suggested that unspliced or not fully spliced mdmx mRNAs are expressed. In addition, we performed an RT-PCR assay on mouse thymus mRNA with one primer derived from exon 2 and another from the following intron. A product of the expected length could be detected, again suggesting that (partly) unspliced mdmx mRNAs are expressed.

The 5' end of CDNA most likely represents the approximate $5^{\prime}$ end of the mRNA, as indicated by $5^{\prime}$ RACE experiments (Shvarts et al., 1996) and because in the mouse genome just upstream of this region promotor activity was found (R.C.A. van Ham and A.G. J ochemsen, unpublished results). From these results we hypothesize that the long mRNAs represent not fully processed mRNA and that the CDNA sequence we 
now show is a representation of the smaller mRNA of $2.2 \mathrm{~kb}$, although other possibilities cannot be excluded. Thus, although we find the human MDMX 10-kb mRNA to be highly expressed in thymus, it remains to be seen whether this has consequences at the protein level. It is not excluded that the unspliced mRNAs also code for Mdmx-like proteins, since in clone 2 an inframe ATG codon is present just eight amino acids in front of the $\mathrm{Mdmx}$-homology region. It will be interesting to find out whether this relatively high mRNA expression will turn out to be important in the differentiation of T-cells or be reflected in a role of MDMX (over)expression in hematological malignancies, as has been reported for MDM2 (Bueso-Ramos et al ., 1993; Maestro et al., 1995; Zhou et al., 1995). MDM2 amplification is found in approximately $30 \%$ of human sarcomas (Oliner et al., 1992). A recent analysis of liposarcomas shows $50 \%$ amplification in $12 q 14$, most probably involving MDM2. In several liposarcomas (4/14) amplification around $1 \mathrm{q} 32$ has also been found, possibly indicating involvement of MDMX (Szymanska et al ., 1996). Whether the MDMX gene is present in this amplicon is currently under investigation.

\section{ACKNOWLEDGMENTS}

We thank Dr. R. Versteeg for screening of the P1 library. We also thank Dr. H.van Dam for critical comments and suggestions, Drs. C. Terleth and $\mathrm{H}$. van Ormondt for critically reading the manuscript, and Ron Schouten for photography.

\section{REFERENCES}

Annweiler, A., Hipskind, R. A., and Wirth, T. (1991). A strategy for efficient in vitro translation of cDNAs using the rabbit beta-globin leader sequence. Nucleic Acids Res. 19: 3750.

Barak, Y., Gottlieb, E., J uven-Gershon, T., and Oren, M. (1994). Regulation of mdm2 expression by p53: Alternative promoters produce transcripts with nonidentical translation potential. Genes Dev. 8: 1739-1749.

Barak, Y., and Oren, M. (1992). Enhanced binding of a 95-kda protein to p53 in cells undergoing p53-mediated growth arrest. EMBO J . 11: $2115-2121$.

Boddy, M. N., Freemont, P. S., and Borden, K. L. B. (1994). The p53associated protein MDM2 contains a newly characterized zinc binding domain called the RING finger. Trends. Biochem. Sci. 19: 198- 199.

Brown, D. R., Deb, S., Munoz, R. M., Subler, M. A., and Deb, S. P. (1993). The tumor suppressor p53 and the oncoprotein simian virus-40 T-antigen bind to overlapping domains on the $\mathrm{mdm} 2$ protein. Mol. Cell. Biol. 13: 6849-6857.

Bueso-Ramos, C. E., Yang, Y., Deleon, E., McCown, P., Stass, S. A., and Albitar, M. (1993). The human MDM-2 oncogene is overexpressed in leukemias. Blood 82: 2617-2623.

Chen, J . D., Lin, J . Y., and Levine, A. J . (1995). Regulation of transcription functions of the p53 tumor suppressor by the $\mathrm{mdm}-2$ oncogene. Mol. Med. 1: 142- 152.

Corvi, R., Savelyeva, L., Breit, S., Wenzel, A., Handgretinger, R., Barak, J ., Oren, M., Amler, L., and Schwab, M. (1995). Non-syntenic amplification of MDM2 and MYCN in human neuroblastoma. Oncogene 10: 1081- 1108.

Feitelson, M. A., Zhu, M., Duan, L. X., and London, W. T. (1993). Hepatitis B $X$ antigen and p53 are associated in vitro and in liver tissues from patients with primary hepatocellular carcinoma. Oncogene 8: 1109- 1117.

Forus, A., Olde Weghuis, D., Smeets, D., F odstad, O., Myklebost, O., and Geurts van Kessel, A. (1995). Comparative genomic hybridization analysis of human sarcomas. I. Occurrence of genomic imbalances and identification of a novel major amplicon at 1q21-q22 in soft tissue sarcomas. Genes Chromosomes Cancer 14: 8- 14.

Francis, F., Zehetner, G., Hoglund, M., and Lehrach, H. (1994). Construction and analysis of the ICRF human P1 library. Genet. Anal. Tech. Appl. 11: 5-6.

Habuchi, T., Kinoshita, H., Yamada, H., Kakehi, Y., Ogawa, O., Wu, W. J ., Takahashi, R., Sugiyama, T., and Yoshida, O. (1994). Oncogene amplification in urothelial cancers with p53 gene mutation or MDM2 amplification. J Natl. Cancer Inst. 86: 1331- 1335.

Haines, D. S., Landers, J . E., Engle, L. J ., and George, D. L. (1994). Physical and functional interaction between wild-type p53 and mdm2 proteins. Mol. Cell. Biol. 14: 1171- 1178.

Hollstein, M., Sidransky, D., Vogelstein, B., and Harris, C. C. (1991). p53 mutations in human cancers. Science 253: 49- 53.

Hollstein, M., Rice, K., Greenblatt, M. S., Soussi, T., Fuchs, R., Sorlie, T., Hovig, E., Smith-Sorensen, B., Montesano, R., and Harris, C. C. (1994). Database of p53 gene somatic mutations in human tumors and cell lines. Nucleic Acids Res. 22: 3551- 3555.

J ones, S. N., Ansarilari, M. A., Hancock, A. R., J ones, W. J ., Gibbs, R. A., Donehower, L. A., and Bradley, A. (1996). Genomic organization of the mouse double minute 2 gene. Gene 175: 209- 213.

Ladanyi, M., Lewis, R., J hanwar, S. C., Gerald, W., Huvos, A. G., and Healey, J.H. (1995). MDM2 and CDK4 gene amplification in Ewing's sarcoma. J . Pathol. 175: 211-217.

Lane, D. P., and Crawford, L. V. (1979). T antigen is bound to a host protein in SV40-transformed cells. Nature 278: 261- 263.

Lianes, P., Orlow, I., Zhang, Z. F., Oliva, M. R., Sarkis, A. S., Reuter, V. E., and Cordoncardo, C. (1994). Altered patterns of MDM2 and TP53 expression in human bladder cancer. J Natl. Cancer Inst. 86: $1325-1330$.

Linzer, D. I., and Levine, A.J . (1979). Characterization of a $54 \mathrm{~K}$ dalton cellular SV40 tumor antigen present in SV40-transformed cells and uninfected embryonal carcinoma cells. Cell 17: 43- 52.

Lyon, M. F., and Searle, A. G. (Eds.) (1989). "Genetic Variants and Strains of the Laboratory Mouse," Second ed., Oxford Univ. Press, Oxford/Gustav Fischer Verlag, Stuttgart.

Maestro, R., Gloghini, A., Doglioni, C., Gasparotto, D., Vukosavljevic, T., Dere, V., Laurino, L., Carbone, A., and Boiocchi, M. (1995). MDM2 overexpression does not account for stabilization of wildtype p53 protein in non-hodgkin's Iymphomas. Blood 85: 32393246.

Maheswaran, S., Park, S., Bernard, A., Morris, J . F., Rauscher, F. J ., Hill, D. E., and Haber, D. A. (1993). Physical and functional interaction between WT1 and p53 proteins. Proc. Natl. Acad. Sci. USA 90: 5100-5104.

Martin, K., Trouche, D., Hagemeier, C., Sorensen, T. S., La Thangue, N. B., and Kouzarides, T. (1995). Stimulation of E2F 1/DP1 transcriptional activity by MDM2 oncoprotein. Nature 375: 691-694.

Moll, U. M., LaQuaglia, M., Benard, J ., and Riou, G. (1995). Wildtype $\mathrm{p} 53$ protein undergoes cytoplasmic sequestration in undifferentiated neuroblastomas but not in differentiated tumors. Proc. Natl. Acad. Sci. USA 92: 4407-4411.

Moll, U. M., Riou, G., and Levine, A. J . (1992). Two distinct mechanisms alter p53 in breast cancer: Mutation and nuclear exclusion. Proc. Natl. Acad. Sci. USA 89: 7262- 7266.

Montes de Oca Luna, R., Tabor, A. D., Eberspaecher, H., Hulboy, D. L., Worth, L. L., Colman, M. S., Finlay, C. A., and Lozano, G. (1996). The organization and expression of the mdm2 gene. Genomics 33: 352-357.

Momand, J ., Zambetti, G. P., Olson, D. C., George, D., and Levine, A. J . (1992). The mdm-2 oncogene product forms a complex with 
the p53 protein and inhibits p53-mediated transactivation. Cell 69: $1237-1245$.

O'Connor, D. J ., Lam, E. W. F., Griffin, S., Zhong, S., Leighton, L. C., Burbidge, S. A., and Lu, X. (1995). Physical and functional interactions between p53 and cell cycle co-operating transcription factors, E2F 1 and DP1. EMBO J . 14: 6184-6192.

Oliner, J . D., Kinzler, K. W., Meltzer, P. S., George, D. L., and Vogelstein, B. (1992). Amplification of a gene encoding a p53-associated protein in human sarcomas. Nature 358: 80- 83.

Oliner, J . D., Pietenpol, J . A., Thiagalingam, S., Gyuris, J ., Kinzler, K. W., and Vogelstein, B. (1993). Oncoprotein MDM2 conceals the activation domain of tumour suppressor-p53. Nature 362: 857860.

Reifenberger, G., Liu, L., Ichimura, K., Schmidt, E. E., and Collins, V.P. (1993). Amplification and overexpression of the MDM2 gene in a subset of human malignant gliomas without p53 mutations. Cancer Res. 53: 2736- 2739.

Sambrook, J ., Fritsch, E. F., and Maniatis, T. (1989). "Molecular Cloning: A Laboratory Manual," Cold Spring Harbor Laboratory Press, Cold Spring Harbor, NY.

Sarnow, P., Ho, Y. S., Williams, J ., and Levine, A. J . (1982). Adenovirus E 1b-58 kd tumor antigen and SV40 large tumor antigen are physically associated with the same $54 \mathrm{kd}$ cellular protein in transformed cells. Cell 28: 387- 394.

Scheffner, M., Werness, B. A., Huibregtse, J . M., Levine, A.J ., and Howley, P. M. (1990). The E 6 oncoprotein encoded by human papillomavirus types 16 and 18 promotes the degradation of p53. Cell 63: 1129- 1136.

Shvarts, A., Steegenga, W. T., Riteco, N., Van Laar, T., Dekker, P., Bazuine, M., Van Ham, R. C. A., Van der Houven van Oordt, W., Hateboer, G., Van der Eb, A.J ., and J ochemsen, A. G. (1996). MDMX: A novel p53 binding protein with some functional properties of MDM2. EMBO J . 15: 5349-5357.

Smith, D. B., and J ohnson, K. S. (1988). Single-step purification of polypeptides expressed in Escherichia col i as fusions with glutathione S-transferase. Gene 67: 31-40.

Srivastava, S., Tong, Y. A., Devadas, K., Zou, Z. Q., Chen, Y., Pirollo,
K. F., and Chang, E. H. (1992). The status of the p53 gene in human papilloma virus positive or negative cervical carcinoma cell lines. Carcinogenesis 13: 1273-1275.

Steegenga, W. T., Shvarts, A., Van Laar, T., Van der Eb, A. J ., and J ochemsen, A. G. (1995). Altered phosphorylation and oligomerization of p53 in adenovirus type 12-transformed cells. Oncogene 11: 49- 57.

Steegenga, W. T., Van Laar, T., Riteco, N., Mandarino, A., Shvarts, A., van der Eb, A.J ., and J ochemsen, A. G. (1996). Adenovirus E 1A proteins inhibit activation of transcription by p53. Mol. Cell. Biol. 16.

Szymanska, J ., Tarkkanen, M., Wiklund, T., Virolainen, M., Blomqvist, C., Askoseljavaara, S., Tukiainen, E., Elomaa, I., and Knuutila, S. (1996). Gains and losses of DNA sequences in liposarcomas evaluated by comparative genomic hybridization. Genes Chromosomes Cancer 15: 89- 94.

Ueda, H., Ullrich, S. J ., Gangemi, J . D., Kappel, C. A., Ngo, L., Feitelson, M. A., and J ay, G. (1995). Functional inactivation but not structural mutation of p53 causes liver cancer. Nature Genet. 9: 41- 47 .

Weissman, B. E., Saxon, P. J ., Pasqaule, S. R., J ones, G. R., Geiser, A. G., and Stanbridge, E.J . (1987). Introduction of a normal human chromosome 11 into a Wilms' tumor cell line controls its tumorigenic expression. Science 236: 175- 180.

Werness, B. A., Levine, A. J ., and Howley, P. M. (1990). Association of human papillomavirus types 16 and $18 \mathrm{E} 6$ proteins with p53. Science 248: 76- 79.

Zantema, A., Schrier, P. I., Davis-Olivier, A., Van Laar, T., Vaessen, R. T. M. J ., and van der Eb, A.J . (1985). Adenovirus serotype determines association and localization of the large E 1B tumor antigen with cellular tumor antigen p53 in transformed cells. Mol. Cell. Biol. 5: 3084-3091.

Zauberman, A., Flusberg, D., Haupt, Y., Barak, Y., and Oren, M. (1995). A functional p53-responsive intronic promoter is contained within the human mdm2 gene. Nucleic Acids Res. 23: 2584- 2592.

Zhou, M., Yeager, A. M., Smith, S. D., and Findley, H. W. (1995). Overexpression of the MDM 2 gene by childhood acute lymphoblastic leukemia cells expressing the wild-type p53 gene. Blood 85: 1608- 1614. 